\title{
Produksi Biomassa Mikroalga (Tetraselmis chuii) Dengan Sistem Pemanenan Berbeda
}

\author{
Ali Djunaedi \\ Jurusan Ilmu Kelautan, Fakultas Perikanan dan Ilmu Kelautan, Universitas Diponegoro \\ JI. Prof. Soedarto, SH. Kampus UNDIP Tembalang, Semarang 50275 \\ Email : alidjunaedi@ymail.com
}

\begin{abstract}
Abstrak
Permasalahan yang sering terjadi adalah masih rendahnya berat biomassa yang dihasilkan pada pemanenan mikroalga. Penelitian bertujuan untuk mengetahui tingkat berat kering biomassa $T$. chuii pada perbedaan sistem pemanenan. Penelitian ini dirancang menggunakan Rancangan Acak Lengkap (RAL) dengan perbedaan sistem pemanenan filtrasi, centrifuge dan flokulasi. Hasil penelitian menunjukkan terdapat perbedaan berat kering biomassa $T$. chuii. Pada sistem pemanenan filtrasi diperoleh berat kering biomassa sebesar 3,899 $\pm 0,073 \mathrm{gr}$, pemanenan centrifuge sebesar 4,242 $\pm 0,129 \mathrm{gr}$ dan pemanenan flokulasi sebesar $5,65 \pm 0,026$ gr. Perbedaan sistem pemanenan memberikan pengaruh sangat nyata $(p<0,01)$ terhadap berat kering biomassa.
\end{abstract}

Kata Kunci : Berat kering biomassa, filtrasi, centrifuge dan flokulasi, Tetraselmis chuii.

\begin{abstract}
Tetraselmis chuii is known as the higher quality natural food. The cultivation of T. chuii produce the high density, but the harvesting systems reduce it. The aim of the research was to find the appropriate harvesting system to the T. chuii biomass production. The $T$. chuii cultivations were done using the 30 liters plastic tank, with three replications. There were three treatments, which were applied, such as: filtration, centrifugation and flocculation, using the Completely Randomized Design. The results of this research showed, that the applied of varying harvesting systems to dry weight of T. chuii biomass was significant difference $(p<0,01)$ respectively. The dry weight of microalgae biomass at applied of filtration system was obtained value of $3,89 \pm 0,073 \mathrm{~g}$, in centrifugation system of $4,23 \pm 0,126 \mathrm{~g}$, and than in the flocculation system of $5,65 \pm 0,026 \mathrm{~g}$.
\end{abstract}

Keywords : Biomass Production; Filtration; Flocculation Centrifugation; Tetraselmis chuii.

\section{PENDAHULUAN}

Bahan bakar minyak merupakan bahan bakar yang sangat diperlukan oleh seluruh masyarakat di dunia. Bahan ini digunakan sebagai sumber energi untuk menggerakkan dunia industri baik industri kecil, menengah maupun industri besar. Namun sumber bahan tambang sifatnya tidak dapat diperbarui, sehingga karena adanya penambangan secara besarbesaran pertahunnya akan menyebabkan kelangkaan bahan tambang minyak sebagai sumber energi utama manusia untuk kegiatan sehari-hari (Christi, 2007).
Salah satu solusi untuk memecahkan permasalahan tersebut adalah mencari sumber bahan baku alternatif untuk dijadikan bahan baku pembuatan minyak. Para peneliti telah banyak menemukan sumber bahan baku minyak alternatif yang berasal dari tanaman pertanian, seperti: kelapa sawit, ketela, jagung dan biji-bijian. Tetapi semua bahan tersebut merupakan sumber bahan baku utama pangan di dunia. Salah satu alternatif sumber bahan baku minyak yang dapat dikembangkan adalah mikroalga. Mikroalga adalah organisme yang berukuran mikro yang terdiri dari satu sel atau beberapa sel yang 
mempunyai bentuk bervariasi yang dapat melakukan fotosintesis dengan memanfaatkan energi cahaya matahari untuk mengubah senyawa anorganik menjadi senyawa organik (Soewardi et al., 2005). Mikroalga yang baik untuk dijadikan sumber bahan baku biodiesel adalah yang memiliki kandungan minyak tinggi.

Salah satu permasalahan dalam proses produksi biodiesel berbasis mikroalga sebagai bahan baku utama adalah di dalam proses pemanenannya, terutama rendahnya biomassa yang dihasilkan dalam proses pemanenan. Rendahnya biomassa yang dihasilkan ini karena sistem pemanenan yang ada sekarang masih sangat konvensional sehingga sangat diperlukan sistem pemanenan yang lebih baik untuk menunjang produksi mikroalga yang tinggi pula. Oleh sebab itu maka perlu diaplikasikan suatu sistem pemanenan yang memungkinkan menghasilkan berat kering biomassa tinggi dalam proses pemanenannya, yaitu: melalui sistem pemanenan centrifuge dan flokulasi.

\section{MATERI DAN METODE}

Penelitian menggunakan mikroalga dari biakan murni mikroalga diperoleh dari Laboratorium Pakan Alami, Balai Besar Pengembangan Budidaya Air Payau (BBPBAP) Jepara dengan kepadatan $10 \times$ $10^{5} \mathrm{sel} / \mathrm{ml}$. Wadah uji yang digunakan berupa wadah plastik PE volume 30 liter sebanyak 9 buah. Media uji berupa air laut dengan salinitas $32 \mathrm{ppt}$ dan temperature 26-28 ${ }^{\circ} \mathrm{C}$. Pengamatan kepadatan sel dilakukan setiap hari setiap 8 jam sekali.

Penelitian ini menggunakan Rancangan Acak Lengkap (RAL) dengan 3 perlakuan 3 kali ulangan. Perlakuan yang digunakan yaitu bermacam-macam sistem pemanenan untuk pemanenan $T$. chuii. Perlakuan tersebut, adalah: pemanenan dengan filtrasi, pemanenan dengan centrifuge dan pemanenan dengan flokulasi(Andayani, T.R. 2009). Parameter pengamatan dilakukan terhadap berat kering biomassa mikroalga. Data hasil pengamatan selama penelitian meliputi berat kering biomassa $T$. chuii, nilai kandungan minyak dianalisis dengan menggunakan analisis varian ( Steel, RGD \& JH. Torrie. 1993).

\section{HASIL DAN PEMBAHASAN}

\section{Kepadatan populasi}

Kepadatan populasi T. chuii yang dikultur selama penelitian diperoleh sebesar $7,62 \times 10^{5} \mathrm{sel} / \mathrm{ml}$. Pola pertumbuhan T. chuii ditunjukkan seperti pada Gambar 1.

Hasil pengamatan kepadatan sel $T$. chuii menunjukkan bahwa puncak kepadatan dicapai pada jam ke 216 dan selanjutnya mengalami penurunan.

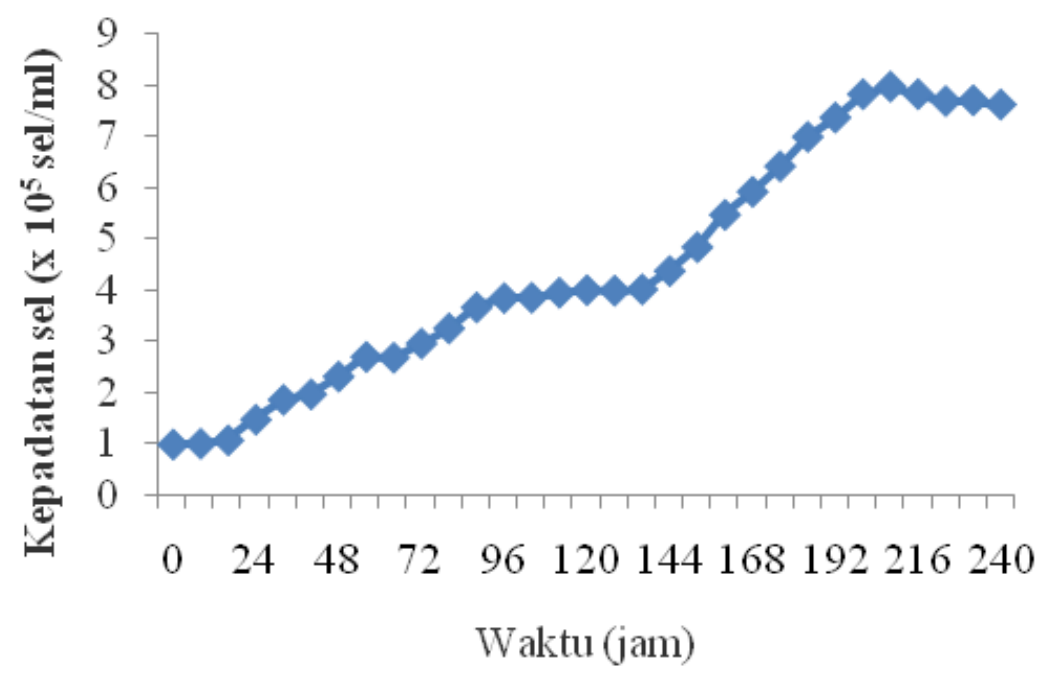

Gambar 1. Grafik pencapaian kepadatan T. chuii yang dikultur selama penelitian 


\section{Biomassa}

Hasil pemanenan T. chuii selama penelitian pada masing-masing perlakuan sebesar 3,89 $\pm 0,977 \mathrm{gr}, 4,24 \pm 0,977 \mathrm{gr}$ dan $5,65 \pm 0,026$ gr. Hasil berat kering biomassa T. chuii (gr) ditunjukkan pada Gambar 2.

Hasil analisis varian data berat kering T. chuii menunjukkan adanya perbedaan yang sangat nyata $(p<0,01)$ pada masingmasing perlakuan. Hal ini menunjukkan bahwa perlakuan pemanenan yang berbeda memberikan respon terhadap berat kering.

Hasil analisis varian data berat kering T. chuii menunjukkan adanya perbedaan yang sangat nyata $(p<0,01)$ pada masingmasing perlakuan. Perlakuan filtrasi menghasilkan berat kering biomassa $T$. chuii yang paling rendah dibanding perlakuan lainnya. Rendahnya berat kering biomassa T. chuii disebabkan karena sistem pemanenan tersebut masih sangat konvensional dan sederhana, yaitu dengan menggunakan kertas saring yang sebelumnya belum dilakukan perlakuan apapun. Sistem pemanenan semacam ini dimungkinkan banyak sel T. chuii yang lolos saat proses pemanenan berlangsung. Hal ini dimungkinkan karena banyaknya sel yang sudah rusak sehingga sel tersebut lolos dari kertas saring. Hal ini terlihat pada proses pemanenan filtrasi di mana pada saat di saring, air hasil saringan tidak jernih dan masih mengandung warna hijau.
Kecilnya ukuran alga menyebabkan penyaringan kurang maksimal dilakukan, karena kertas saring yang digunakan di bawah ukuran sel dari T. chuii. Benemann dan Oswald (1996), menyatakan bahwa teknik pemanenan secara filtrasi akan lebih efektif digunakan untuk pemanenan jenis alga yang berfilamen, seperti Spirulina platensis.

Sistem pemanenan ke dua adalah dengan cara centrifuge. Sistem kerja centrifuge pada umumnya memisahkan sel T. chuii dengan air berdasarkan perbedaan berat molekul. Ini diperkuat dengan pendapat berbagai peneliti (Mohn, 1988; Olaizola, 2003) yang menyatakan, bahwa sistem pemanenan dengan centrifuge adalah suatu metode pemisahan mikroalga dari medium dengan menggunakan suatu peralatan pemusing, sehingga mikroalga tersebut terpisah dari air. Penggunaan centrifuge menyebabkan terjadinya pemisahan sel-sel T. chuii dari air, di mana $T$. chuii mengalami pengendapan berbentuk lapisan di bawah tabung reaksi setelah proses centrifuge. Proses ini memungkinkan dalam proses penyaringan dihasilkan biomassa yang lebih tinggi dibanding perlakuan filtrasi.

Pada penerapan sistem pemanenan $T$. chuii dengan cara flokulasi menunjukkan hasil berat kering biomassa tertinggi (Gambar 2). Tingginya berat kering biomassa $T$. chuii yang dihasilkan disebabkan karena pada perlakuan

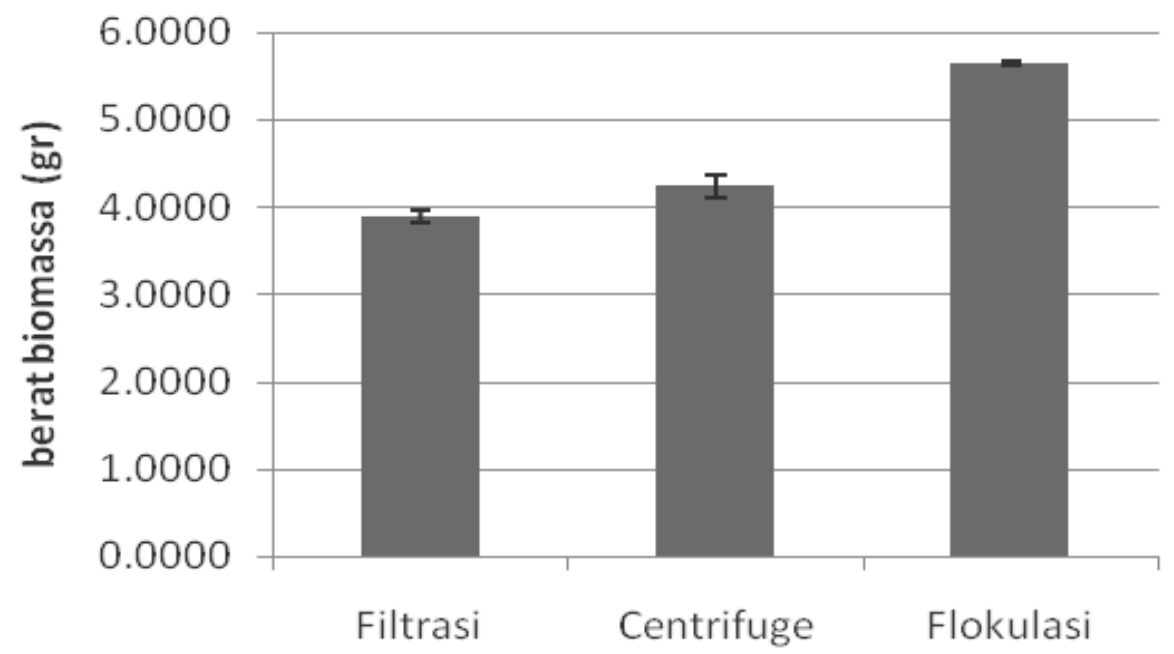

Gambar 2. Diagram berat kering biomassa T. chuii dari masing-masingperlakuan perbedaan sistem pemanenan. 
sistem flokulasi dihasilkan pengendapan partikel-partikel flok yang lebih cepat sebagai akibat dari adanya peningkatan ukuran partikel dan densitas dari partikel yang terkoagulasi. Hal ini dipertegas oleh pendapat Knuckey et al. (2006) yang menyatakan, bahwa teknik flokulasi dilakukan untuk menciptakan kumpulan atau flok mikroalga, sehingga dengan mudah biomassa dapat dipindahkan dari air. Kecepatan pengendapan partikel flok akan dipercepat lebih lanjut dengan adanya penambahan flokulan.

Flokulan merupakan senyawa yang digunakan untuk membentuk senyawa dari polutan yang mudah mengendap dan atau senyawa yang mempunyai ukuran yang lebih besar dengan suatu reaksi kimia. Benemann dan Oswald (1996) menyatakan bahwa flokulan-flokulan kimia telah digunakan untuk meningkatkan proses terjadinya gumpalan dalam beberapa dekade. Flokulan-flokulan mendorong pembekuan/pengentalan mikroalga untuk membentuk ukuran flok yang lebih besar dan kemudian kumpulankumpulan tersebut bisa dipanen. Poleman et al. (1997) berdasarkan hasil penelitiannya memperjelas bahwa teknik flokulasi terbukti efektif menghasilkan biomassa paling tinggi dibanding teknik pemanenan lain, seperti penyaringan, centrifuge dan pengapungan.

\section{KESIMPULAN}

Perbedaan sistem pemanenan memberikan pengaruh perbedaan sangat nyata $(p<0,01)$ terhadap berat kering biomassa T. chuii. Pada sistem pemanenan filtrasi diperoleh berat kering biomassa terendah yaitu 3,899 $\pm 0,073 \mathrm{gr}$, pemanenan centrifuge sebesar 4,242 \pm $0,129 \mathrm{gr}$ dan pemanenan flokulasi yang tertinggi sebesar 5,65 $\pm 0,026 \mathrm{gr}$.

\section{DAFTAR PUSTAKA}

Andayani, T.R. 2009. Analisis Asam Lemak Mikroalga Tetraselmis chuii. Intitut Tehnologi Surabaya. Surabaya

Benemann, J.; Oswald, P.I. 1996: Systems and Economic Analysis of Microalgae
Ponds for Conversion of CO2 to Biomass. Department Of Energy Pittsburgh Energy Technology Center,. No: DOE/PC/93204-T5.

Bosma, R. Vanspronsen, W. A. Tramper, J. Wijffels, R. H. 2003. Ultrasound, a new separation technique to harvest microalgae. J. Appl. Phycol., 15 (2-3). 143-153.

Chrismadha, T, D. Suryatini dan Y. Mardiati. 2007. Respon kultur mikroalga dalam fotoreaktor tegak berpenyekat terhadap variasi intensitas cahaya. Puslitbang Limnologi - LIPI. Oseanografi dan Limnologi, 33: 245 256.

Christi, Y. 2007. Biodiesel from microalgae. Biotechnology Advances, 25: 294-306.

Cohen, Ephraim, Koren, Avi and Arad, Shoshana M. 1991. A Closed System for Outdoor Cultivation of Microalgae. Biomass and Bioenergy. Vols. 1, 2:83-88.

Ghozali, Imam. 2005. Aplikasi Analisis Multivariate Dengan Program SPSS. Badan Penerbit Universitas Diponegoro. Semarang. 53-75 HIm

Knuckey, R. M.; Brown, M. R. Robert, R. Frampton, D.M.F. 2006. Production of microalgal concentrates by flocculation and their assessment as aquaculture feeds. Aquacult. Eng. 35(3), 300-313.

Mohn, R.H. 1988. Harvesting of Micro-algal Biomass. Microalgal Biotechnology, Cambirdge U. Press. 334-338 $p$

Molina Grima, E. Belarbi, E. H. Acien Fernandez, F. G. Robles Medina, A. Chisti, Y. 2007. Recovery of microalgal biomass and metabolites: Process options and economics. Biotechnol. Adv. 20 (7-8), 491-515.

Olaizola, M. 2003. Commercial development of microalgal biotechnol- ogy: From the test tube to the market place. Biomol. Eng., 20 (46), 459-466.

Poleman, E., De Pauw, N. \& Jeurissen, B. 1996. Potential of electrolytic flocculation for recovery of microalgae. Resources, Conservation and Recycling 19 (1997) 1-10.

Schenk, PM., Thomas-Hall, SR., Stephens E., Marx, UC., Mussgnug, JH., Posten, C., Kruse, O., Hankamer, B. 2008. Second 
generation biofuels: high-efficiency microalgae for biodiesel production. Bioenerg. Res. 1: 20-43

Steel, RGD \& JH. Torrie. 1993. Prinsip dan Prosedur Statistika. Suatu Pendekatan Biometrik. Gramedia Pustaka Utama. Jakarta. $748 \mathrm{HIm}$.

Soewardi, K., N. Pratiwi dan Messenreng. 2005. Komposisi dan kelimpahan fitoplankton crysophyta (Phaeodactylum sp., Chaetoceros sp. dan Pavlova sp.) pada berbagai tingkat kandungan unsur hara nitrogen, fosfor dan silikat. JIPPI. 12(2):73-168.

Taw, N. 1990. Petunjuk Pemeliharaan Kultur Murni dan Massal Mikroalga. Proyek Pengembangan Budidaya Udang: United Nation Development Programme Food And Agriculture Organization of The United Nations. US. $34 \mathrm{HIm}$. 